\title{
Self-organisation and meaning of urban structures: case study of Jewish communities in central Poland in pre-war times
}

\author{
Malgorzata Hanzl \\ Institute of Architecture and Town Planning. Lodz University of Technology. Lodz. Poland \\ E-mail:mhanzl@p.lodz.pl
}

\begin{abstract}
In spatial, social and cultural pluralism, the questions of human intentionality and socio-spatial emergence remain central to social theory. The correlation between individual preferences, values and intentions, and actual behaviour and actions, is subject to Portugali's theory of self-organisation. The key feature in how complex systems 'self-organise', is that they 'interpret', the information that comes from the environment. The current study explores the urban environment formerly inhabited, and largely constructed, by Jews in two central Polish districts: Mazovia and Lodz, before the tragedy of the Holocaust. While the Jewish presence lasted from the 11 th century until the outbreak of World War II, the most intensive development took place in the 19th century, together with the civilisation changes introduced by industrialisation. Embracing the everyday habits of Jewish citizens endows the neighbourhood structures they once inhabited with long gone meanings, the information layer which once helped organise everyday life. The main thesis reveals that Jewish communities in pre-war Poland represented an example of a self-organising society, one which could be considered a prototype of contemporary postmodern cultural complexity. The mapping of this complexity at the scale of a neighbourhood is a challenge, a method for which is addressed in the current paper. The above considerations are in line with the empirical studies of the relations between Jews and Poles, especially in large cities, where more complex socio-cultural processes could have occurred.
\end{abstract}

Keywords: Urban morphology, meaning, complexity, outdoor space, socio-spatial configuration, self-organisation.

\section{Introduction}

The current study explores the urban environment formerly inhabited, and largely constructed, by Jews in two central Polish districts: Mazovia and Lodz, before the tragedy of the Holocaust. While the Jewish presence lasted from the 11th century until the outbreak of World War II, the most intensive development took place in the 19th century, together with the civilisation changes introduced by industrialisation. The unique character of the urban structures in many locations of central Poland deserves to be attributed to their former Jewish citizens.
This objective however requires an in-depth understanding of the culture which created them. This paper provides a summary of the larger research on the idiosyncrasies of former Jewish neighbourhoods in central Poland in the pre-war period (Hanzl 2017).

Embracing the everyday habits of Jewish citizens endows the neighbourhood structures they once inhabited with long gone meanings, the information layer which once helped organise everyday life. Much has been written on the research into material culture, a method has been derived from several disparate yet seminal theoretical works in social anthropology, urban morphology and 
complexity studies. As a result, the study has revealed a set of features relevant to the neighbourhoods populated by Jews in pre-war times, describing their particular character which is repeated in most Polish towns and neighbourhoods. Apart from depicting changes to civilisations as a result of time span, which for Polish Jews lasted ca. one thousand years, we need also to take into consideration the complexity stemming from, on the one hand the enrichment of professional opportunities, on the other acculturation and transformations of religious life as a consequence of the development of Hasidism and reformed Judaism, as well as changes resulting from the rich political life.

\section{Methodology and thesis}

One of the main goals of the project is to define a methodology for the description of idiosyncrasies of urban outdoor spaces in relation to the cultural background of their inhabitants, aimed at enabling an understanding of the relations between urban scapes and the human behaviour which they embrace. The relations between social activities, urban culture and urban form have been studied simultaneously, using research methods from anthropology and urban morphology as well as insights from complexity studies.

As Jews in the period preceding the World War II were an extremely divergent group, the classification has been conceived to allow the explanation of various forms of cityscapes developed from the same cultural background through adoption of habits and lifestyles connected with the ranges of cultural assimilation. It allows one to distinguish the conscious and formalised forms of equipment of public spaces from the unconscious order of space (Figure 1). In spatial, social and cultural pluralism, the questions of human intentionality and socio-spatial emergence remain central to social theory (Portugali 2000, p.142). The correlation between individual preferences, values and intentions, and actual behaviour and actions, is subject to Portugali's theory of self-organisation (2000). Compared to Gidden's structuralism, which focuses on society and groups, the point of departure for Portugali (2000) are individuals and their personal choices. The key feature in how complex systems 'self-organise', is that they 'interpret', the information that comes from the environment (Portugali 2006).

The main thesis reveals that Jewish communities in pre-war Poland represented an example of a self-organising society, one which could be considered a prototype of contemporary postmodern cultural complexity. The mapping of this complexity at the scale of a neighbourhood is a challenge, a method for which is addressed in the current paper. The above considerations are in line with the empirical studies of the relations between Jews and Poles, especially in large cities, where more complex socio-cultural processes could have occurred

\section{Research outcomes \\ Complexity and self-organisation}

Along with the progressing modernity and industrialisation, the homogenous traditional Jewish culture was gradually replaced with a palimpsest of intellectual threads and traditions. The traditional society offered a livelihood in a highly defined and hierarchical structure, but with the abolishment of the noble economy and the increasing industrialisation, this former stability was lost. Deprived of this economic base, with the changing conditions of local communities no longer providing sufficient support for their poor, Jewish masses were forced to look after themselves. Population growth and the shrinking market for their services in locations they had lived until then, together with the opportunities which opened up thanks to the development of industry and the growth of new administrative centres, forced crucial changes in Jewish society. This was the situation when, with the progressing development of secular education, and thereby individualism, more and more actors started planning and re-planning their individual activities, looking for new routines. The Jewish population, accustomed to adjusting to the decisions of governing bodies, in the period of transition from a high context culture to a low 
context one, again easily adjusted, however, this time their choices were based more on individual and family decisions than those of the community.

In the case of Lodz and Mazovian districts, urbanisation intensified in two crucial periods: The Middle Ages, when towns were laid out under German town law, and the beginnings of the industrial era - around the thirties of the 19th century. In the latter, the government of the Kingdom of Poland began activities towards the industrialisation of formerly rural or forested parts of Gubernia Piotrkowska. Thus, when looking at the town plans, we may see mainly elements coming from these two periods. People who occupied these layouts chose, more or less deliberatively, their place of living and erected structures which not only suited their requirements and contained the economic activities they performed but were also subject to various limitations and rules. Against the backdrop of economic activities, individual decisions were made, following individual preferences and systems of values, as well as the outset preconditions, such as economic capacities. We may presume that there was opposition between the highly centralised hierarchical and, to a large extent, oppressive nationalist practices of planning, and "the highly distributed, diffused and decentralised urban tradition" (Portugali 2000, p.247).

The model defined by Portugali (2000, p.243) as a new order-parameter plan is applied to the current case study; the constant migrations and adaptations to the situation of the already established or newly-formed urban centres being a typical reality for Jewish citizens in pre-war Poland. Both scenarios which Portugali distinguishes remain relevant here. On the one hand Jews adapted to the reality of towns they arrive to or, in the language of complexity studies, they became enslaved in the system of norms which ruled in the place before their arrival. On the other hand, they affected this new reality, adjusting it to their needs and the system of rules and values appropriate to their own culture. Their activities triggered transformations, their active involvement fostering urbanisation processes. We may also establish a time-scale, as some larger and shorter processes coexisted in the system. Cities which had served as primary or secondary administrative centres for years, were permanent magnets for Jewish communities, who had lived there since the Middle Ages. These processes provided the background for the much speedier development of industrial towns, some booming then declining very rapidly, others observing a more stable development, or, like Lodz, growing into a metropolis. The main synopsis of the database model of the Jewish population in the current Mazovian and Lodz voivodships in 1921 has been developed based on census data (Figure 2).

The idea of self-organisation is crucial, as it shifts the understanding of agency. In a historical sense, it has been, up to now, recognised that a society, especially the Jewish society in pre-war Poland, had very little influence on the actual appearance of cities, or at least did so in a way that was hard to define. Looking at the same historical facts from the perspective of self-organisation, we start to recognise their role in the urbanisation process. As particularly mobile citizens, Jews significantly altered the dynamics of urban growth. Performing the range of professional activities they did, they undeniably influenced local economies. They also influenced the form of dwellings and tenements, which, originally universal and adaptable, had to now accommodate Jewish families, with their specific habits. Among the neighbourhoods they picked to live in, there were linear structures, more concentrated ones, and even those which adopted much more contemporary models of dispersed urbanisation. In certain settlements, differing models developed one next to another, representing different cultures of the usage of space.

\section{Types of culture: high context versus low context cultures}

The current study provides the initial framework to map the spatial distribution and investigate the morphology of Jewish settlements in central Poland. The data collected reveals the 
following features which differed between towns and neighbourhoods:

-acculturation level and attitude towards religion,

-main professional profile of a settlement or of a neighbourhood,

-size of a community.

Additionally, these characteristics changed over time, with new layers resulting from industrialisation and the development of modern administration overlapping with the former urban centres coming from the period of merchant urbanisation (Lefebvre 2003 and Portugali 2000, p.312). At the turn-over of the 19th and 20th century, an utterly new phenomena emerged within Jewish society with the development of the awareness of the benefits and dangers of industrial cities; the quest for healthy living, identified then with escape from cities, led to the development of summer resorts and so called garden cities.

The loss of the former stability as a result of industrialisation led to a dissipation of traditional society defined structures. First and foremost, the primary feature which characterised the form of neighbourhoods inhabited by Jews between the wars was the lack of homogeneity. The variety of Jewish cultures at the time found its reflection in the variety of urban settings they inhabited. While the meaning of some elements remained virtually unchanged through the ages, new threads appeared, not just acculturation and modernisation, but also as a consequence of the huge development of the Hasidic community, or thanks to the influx of Russian Jews at the end of the 19th century for example.

The transition from a high context culture towards a lower definition of context was reflected in the form and distribution of urban structures. Jewish Orthodox and Hasidic culture in Poland in the period before World War II was a high context one. The more assimilated groups inhabited much more heterogeneous neighbourhoods, located in parts of cities founded under the architectural rules of Classicism, geometry played the mayor role in shaping plans. While there were usually many shades and taints of everyday culture, depending on the actual origins, profession, religious group, and so on, this basic distinction was quite explicit and rigid, and the division strict. In more traditional neighbourhoods, the former planning was preserved, with denser network of more winding streets, backyards often being isolated from the surrounding space, etc.

In smaller towns, the Jewish communities were not big enough to develop more heterogeneous lifestyles. These traditional religious communities conducted their strict, religion-based lives of the former "shtetl"-like culture. Some of them did so unconstrained by the close vicinity of large urban centres. In metropolitan cities, like Lodz and Warsaw of the beginning of the 20th century, the richness of the variety of everyday practices led towards the overlaying of spatial threads on top of others.

\section{Spatial order and meaning}

A range of features confirm the impact of a system of norms and specific semiological connotations belonging to the Jewish culture on the urban settings they inhabited. First, a trait which strikes when reading descriptions of Jewish traditional neighbourhoods by various authors is the utterly different attitude and evaluation of these settings' aesthetic values by Jewish and non-Jewish authors. Hubka (2005) attributes the dense, non-geometric spatial layout of Jewish districts in small towns of the eighteenth century to the incremental growth and restrictions placed upon the Jewish community through legal regulations. Not only did the old shtetlech continue, steadily transformed and adjusted to modernisation, but their layouts were re-established in the new places where the orthodox communities moved. Along with this displacement to larger urban centres, Jews, tightly attached to their traditions, continued their former habits and recreated the former settings in new places, often, due to the changes of architectural forms, with different materials and physical structures.

The three main spheres of Jewish life feature sacrum, profanum and domestic space. In the first sphere of sacrum, the focus was initially on the synagogue, which later expanded to several 
additional structures, at first beit midrash, then yeshivas and shtibl. With time, the development of the Hasidic movement and the growth and diversification of Jewish society, further fragmentation progressed and the role of the synagogue was partly transferred to numerous prayer houses. The concentric nature of Jewish spaces is particularly apparent when looking at synagogues' courtyards, which, set back inside a block's interior, gathered around itself all the necessary community institutions. Traditionally, synagogues did not presume to have any sort of formal representation in the public realm, they often remained secluded and hidden inside urban blocks. With time, their functions were dispersed, but the main rules of spatial organisation remained. Along with Jewish integration into Polish society and progressing acculturation, synagogues assumed a more imposing appearance and became visible and dominant in public space.

In the profanum sphere, the focal point was the market place, Jews tended to settle in the proximity of the main square, which attracted them by catering to their economic needs. However, commercial activities were never limited to the market only; they extended to the neighbouring streets, passages, gates of tenements surrounding public spaces and shops and workshops in the proximity and further. Not only did this refer to commercial aspects but also spaces of production, manufacturers' workshops, small factories, etc. In some places this network of exchange and production spaces could even extend to neighbouring smaller towns, such as in case of Łódź and Brzeziny.

The third focal point was interior streets, courtyards and, in later times, backyards (Figure 3) where daily life took place. Specific forms of dwellings, often very small and hosting a variety of activities, forced people to use backyards as an extension of private space. The role of the backyard and its contribution to the outdoor space of the community may be considered as the centre of neighbourhood life. It focused on domestic activities, but served also as communal space, this way enhancing the relations within the community.

\section{Meaning - pragmatics}

Further analyses conducted in the current study comprised an attempt to understand the meanings conveyed by built structures. The conscious portion of the message delivered by the built environment through signs understood in a given cultural context (Eco 1997) refers to the pragmatics of outdoor space, understood as activities which take place in a given site (Rapoport 1990, p.38).

In the category of fixed features, a special place belongs to buildings which, due to their specific functions, conveyed explicit and easy to read meanings. The discussed neighbourhood hosted both edifices and facilities which served to satisfy the needs of the Jewish community, the specific features of which were regulated by norms. These structures may be divided into the same three groups which were provided above as the main focus of Jewish every-day life: sacred-religious, profanum and domicile. While in traditional Jewish culture all the community facilities were inherently associated with religious life, along with acculturation, this trait changed and the functions separated.

Along with fixed ones semi-fixed features, for instance advertisements, outdoor space equipment, small architecture, etc., and informal, non-fixed-features, could also communicate the ways of life in this environment. Service and commercial activities were the easiest to decipher, the more so that the customers using the services, were not only of Jewish origins. Wherever the requirements of outdoor commerce imposed the necessity of large open spaces, they were occupied by stalls and stands, usually ordered but still competing for the attention of passersby. Very judicial management of space, little space without a prescribed use, and frequent overlapping and synergy of different uses of the same space completed the above picture. The space for commerce was not restricted to the main square, it was present in the neighbouring streets and passages. Jewish streets abounded with advertisements, placards, commercials, external stalls, etc. Often shifted to the centre of the pavement, the stalls of street vendors competed for the attention of passers-by. Commercial streets and squares, together 
with neighbouring backyards have usually been depicted as cramped and cluttered with merchandise. The abundance of border space facilitated the placement of numerous objects of outdoor commerce, such as stalls, stands, etc. Their presence and arrangement was subordinated to the needs of circulation inside and to the best exposition of merchandise, with stalls formed rows along internal alleys, protruding as much as possible into the walking space. All these semi-fixed and non-fixed but somehow permanent features easily defined the meaning of spaces and the structures next to them.

\section{Proxemics}

Next to articulated, pragmatic messages, which conveyed cues on the culturally established activities, additional conditions were communicated through the forms of urban settings: their scale, distribution of structures, rhythms, corrugation of facades, types of ceilings and pavements and other elements defining urban forms. This unconscious part of communication through the intrinsic organisation and arrangement of urban forms, contributed to the specific spatial order of Jewish spaces.

Proxemics yields further understanding of the nature of relations between the human environment and behavioural patterns (Hall 1966, 2009). The short interpersonal distances had their reflection in the preferred scale of physical outdoor space created by Jews. Hence, as a rule, in traditional Jewish neighbourhoods the streets were narrower than elsewhere. Limited scale prevailed in the majority of pre-war traditional Jewish neighbourhoods, especially featuring in internal streets, passages, alleys, nooks, etc. The scarcity of available space meant that all places, even the smallest, were intensively used and often crowded.

The city, seen in Hillier's (2012) opinion as a system of visual distances, with large streets and avenues of higher connectivity and exposure, in traditional Jewish perception must have appeared alien and external. The aforementioned narrowness of backyard passages and presence of numerous directional differentiation provided the notion of concavity. Hence, the facades closed the perspective and assured a perceived and felt enclosure inside urban blocks. For their collective life, Jews seemed to build their own city within a city, consisting of passages of smaller scale and focused inwardly. In cases when the grain of urban blocks was finer, such as in Bałuty in Łódź, some streets functioned as part of internal space. However, Jewish quarters were not closed completely, they protruded into their surroundings with purely functional spaces of commerce and services. Instead however of looking for social integration with the external Polish community, Jews, literally and metaphorically, turned their backs, with their communal life revolving around enclosed spaces inside. The communal institutions either were located inside urban blocks or were hidden within an urban block. This seems to be in direct contrast to the patterns common for surrounding cultures, where public squares were designed as places of communal, urban life. With progressing acculturation, the contrasts diminished and many customs and ways of building converged, the phenomena referring initially to reformed synagogues, which took on the appearance and landmark position modelled on Christian churches.

\section{Conclusions}

The observations made in the current study confirm the thesis that Jewish communities in pre-war Poland may be considered an example of a self-organising society, one which could be considered a prototype of contemporary postmodern cultural complexity. The model of a new order parameter plan (Portugali 2000, p.243) entirely applies, Jewish citizens in pre-war Poland used to migrate and adjust to external conditions, either enslaved in the system of norms which ruled in the place before their arrival, or adapting it to their own needs. The meanings conveyed by built structures, which ruled their choices, reflected three main spheres of Jewish life which were: sacrum, profanum and domicile.

What's more, the presented analyses have 
proved the existence of a separate spatial order specific for the distinguishable Jewish traditional culture which once developed in Poland. Two different cultures using the same spaces perceived and evaluated spatial order differently. When describing cultures, Hall (1966) distinguishes two basic categories; that of a more concentric or a more linear nature. I believe this was one of the key differences between traditional Polish and Jewish organisation of space in pre-war times, Jewish culture being of a more concentric nature. The initial layout was in both cases the same, and in many situations consisted of medieval patterns of towns founded under German law, however, as shown in the current book, other layouts were also adapted - the Jewish quarters could develop inside a block of Baroque settlement (as the example of Góra Kalwaria confirms) or the development might begin from the founding of a town, such as in Otwock.

Intellectual threads / religious movements / migrations / political threads

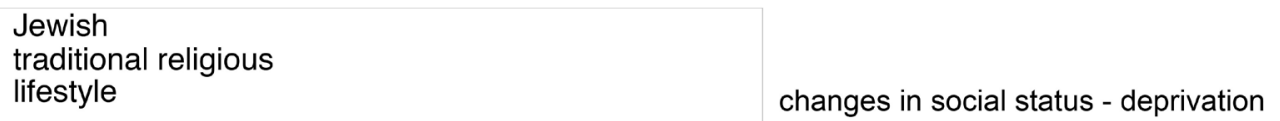

Partitions of Poland: $1772,1793,1795$

\begin{tabular}{|l|l|l|l|}
\hline \begin{tabular}{|l|l|} 
Misnagdim \\
[Opponents]
\end{tabular} & $\begin{array}{l}\text { Hasidism } \\
\text { early 18th century, } \\
\text { Baal Shem Tov }\end{array}$ & $\begin{array}{l}\text { Haskalah } \\
\text { Jewish } \\
\text { Enlightenment }\end{array}$ \\
\cline { 2 - 4 } & $\begin{array}{l}\text { Litvacs } \\
1881-1882, \\
1905-1907 .\end{array}$ & \\
\hline
\end{tabular}

World War I

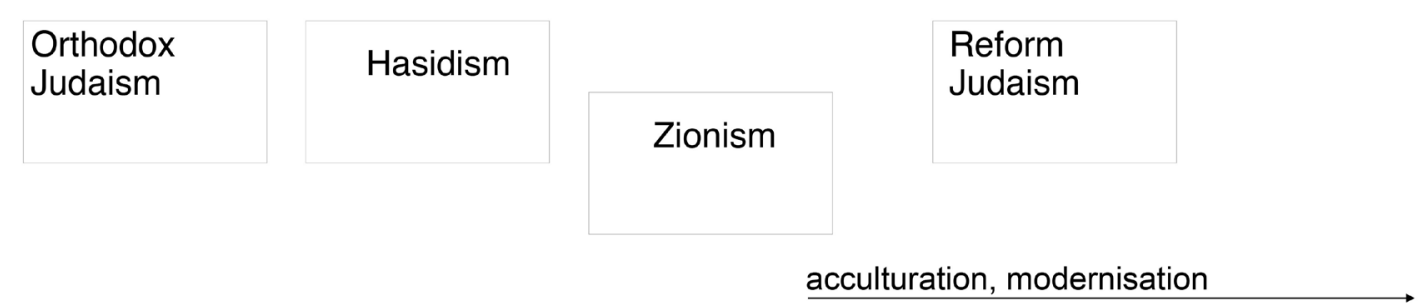

Figure 1. An attempt at a visual classification of the diversity of Jewish culture in pre-war Poland. 


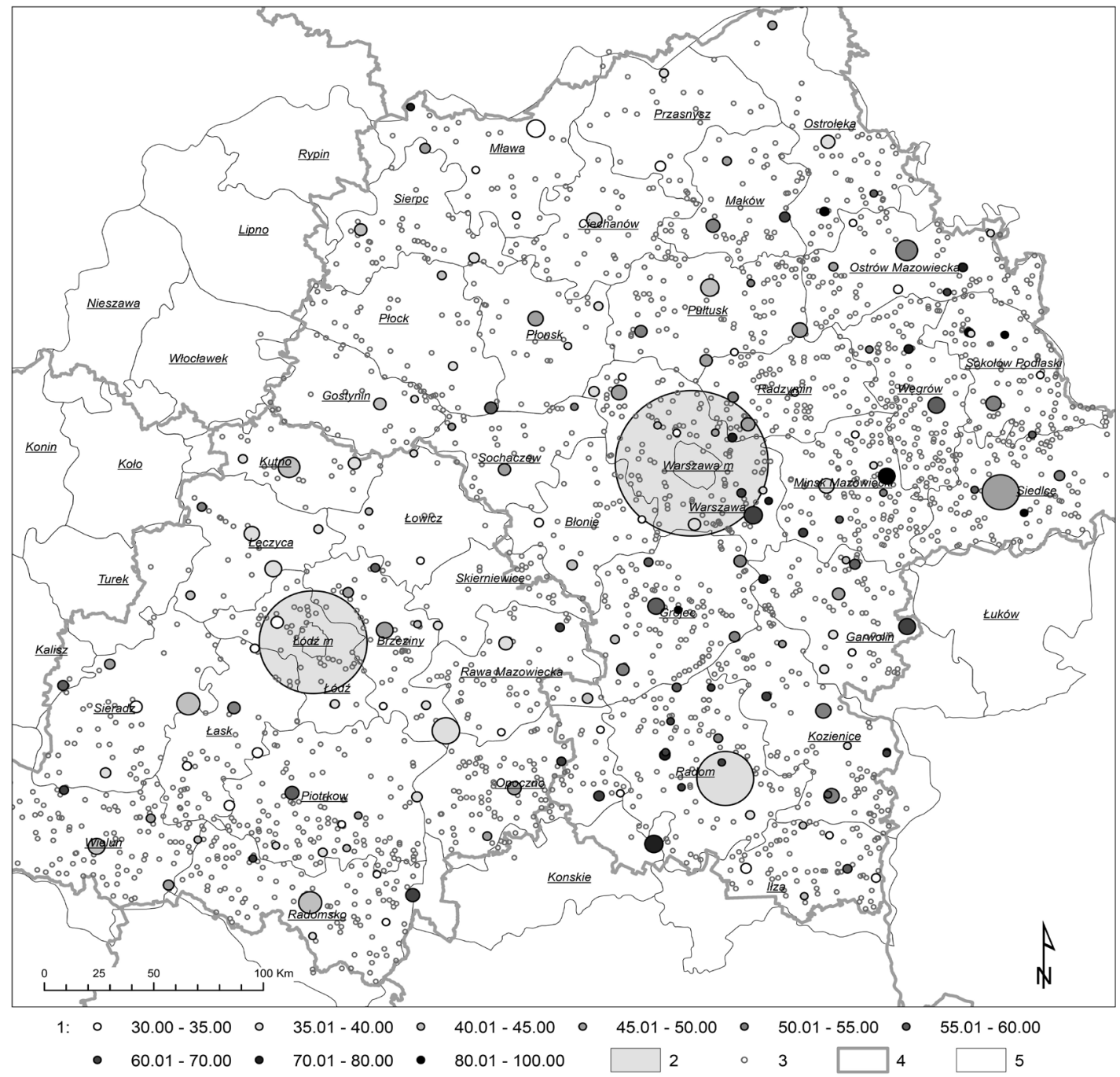

Figure 2. Settlements with over 50 Jews where they provided for 30 and more percent of the total population (GUSRP 1925). 1. percentage of the Jewish population in towns and villages, dot sizes describe the size of a Jewish population, 2. regional centres: Warsaw, 3. remaining towns and villages with a Jewish population, 4. contemporary voivodeships borders, 5. pre-war county borders. 


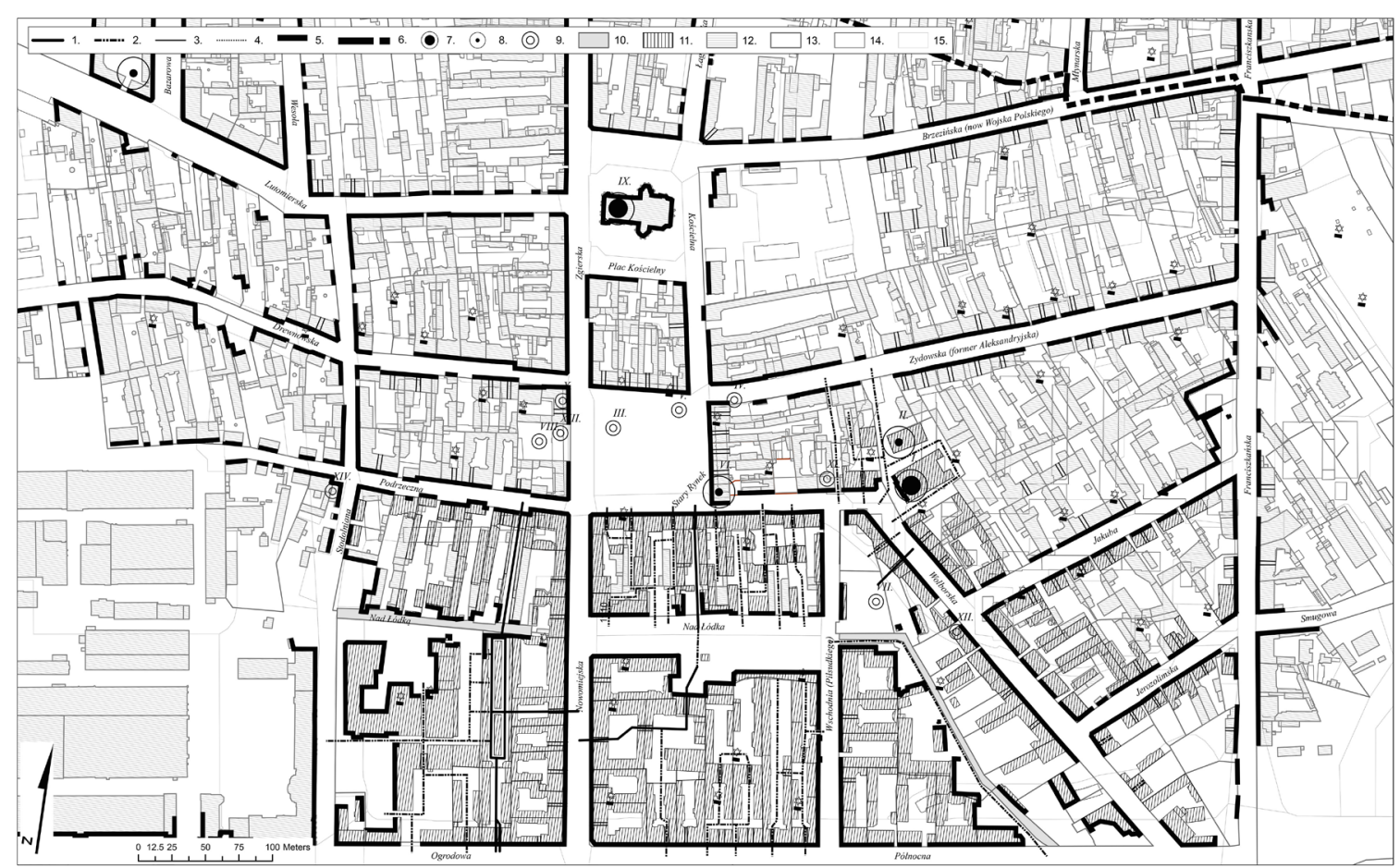

Figure 3. Old Town - an analysis of the form of the public realm. Section $2 \mathrm{~b}$. The sociometric layout of paths and alleys has been presented on the backdrop of the reconstruction of the formerly-existing quarter between Nad Lódką Street, Stodolniania

Street and Pólnocna Street in Lódź. The quarter, inhabited mainly by Jews, was demolished by Germans in 1939. The reconstruction has been done for the purpose of the making of a large-scale model of the quarter by a team of the Museum of the History of the City of Lodz: M. Gruda, A. Brajter, B. Polewczyk, modelling team: B. Michalski,

S. Matusiak. 1. main confirmed commercial paths, 2. remaining internal paths, hypothetical, 3. location of gates in tenements, 4 . unconfirmed gates, 5 . street facades, 6. administrative border of Lodz before World War I, streets, 7. distant landmarks, 8. landmarks, 9. other significant locations, 10. prayer houses according to Rykała (2012),

11. river Lódka, 12. buildings' layout based on the model reconstruction 1939, 13. buildings' layout based on German maps of 1939, source State Archives of Lodz, 14. plot borders 1939, 15. buildings 2000, 16. plot borders 2000. 


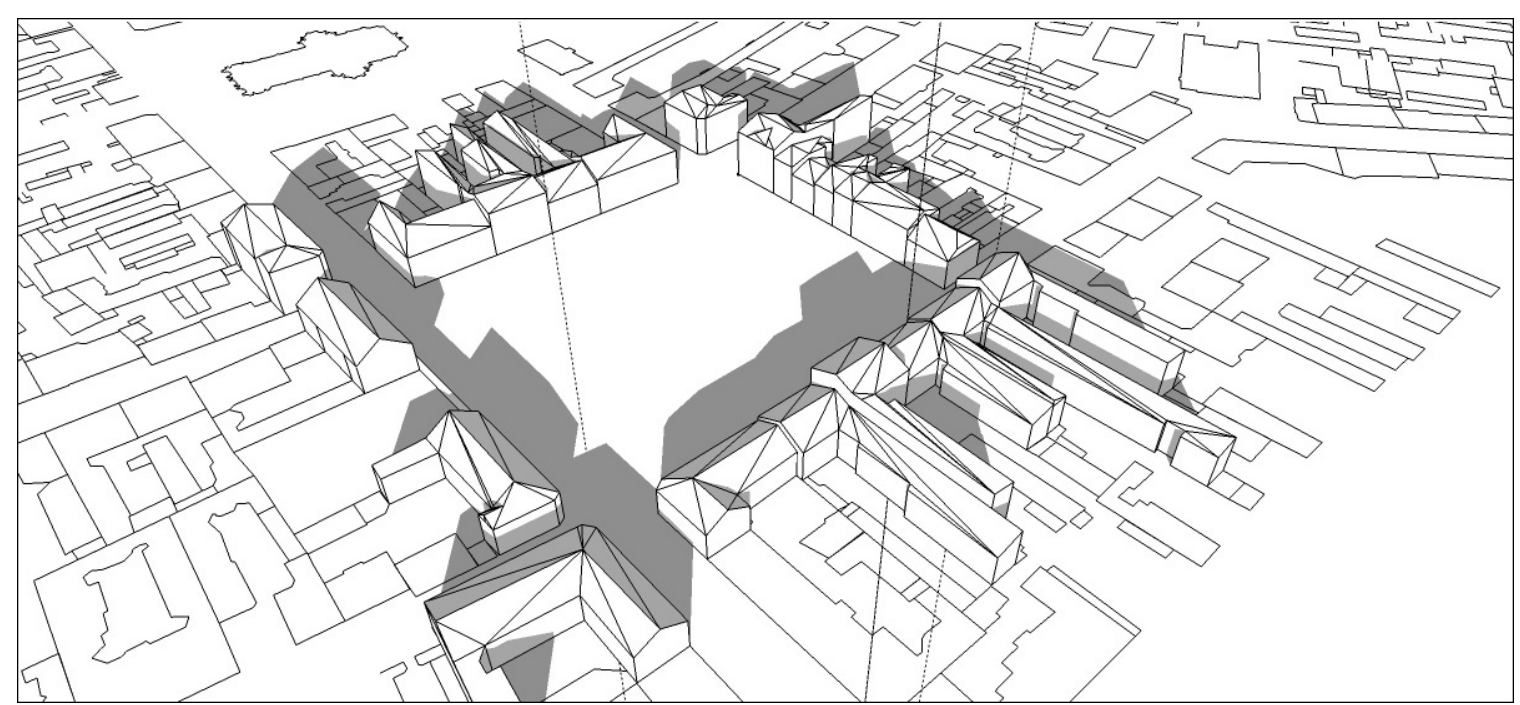

Figure 4. The Old Market in Lodz - a reconstruction of its state before World War II.

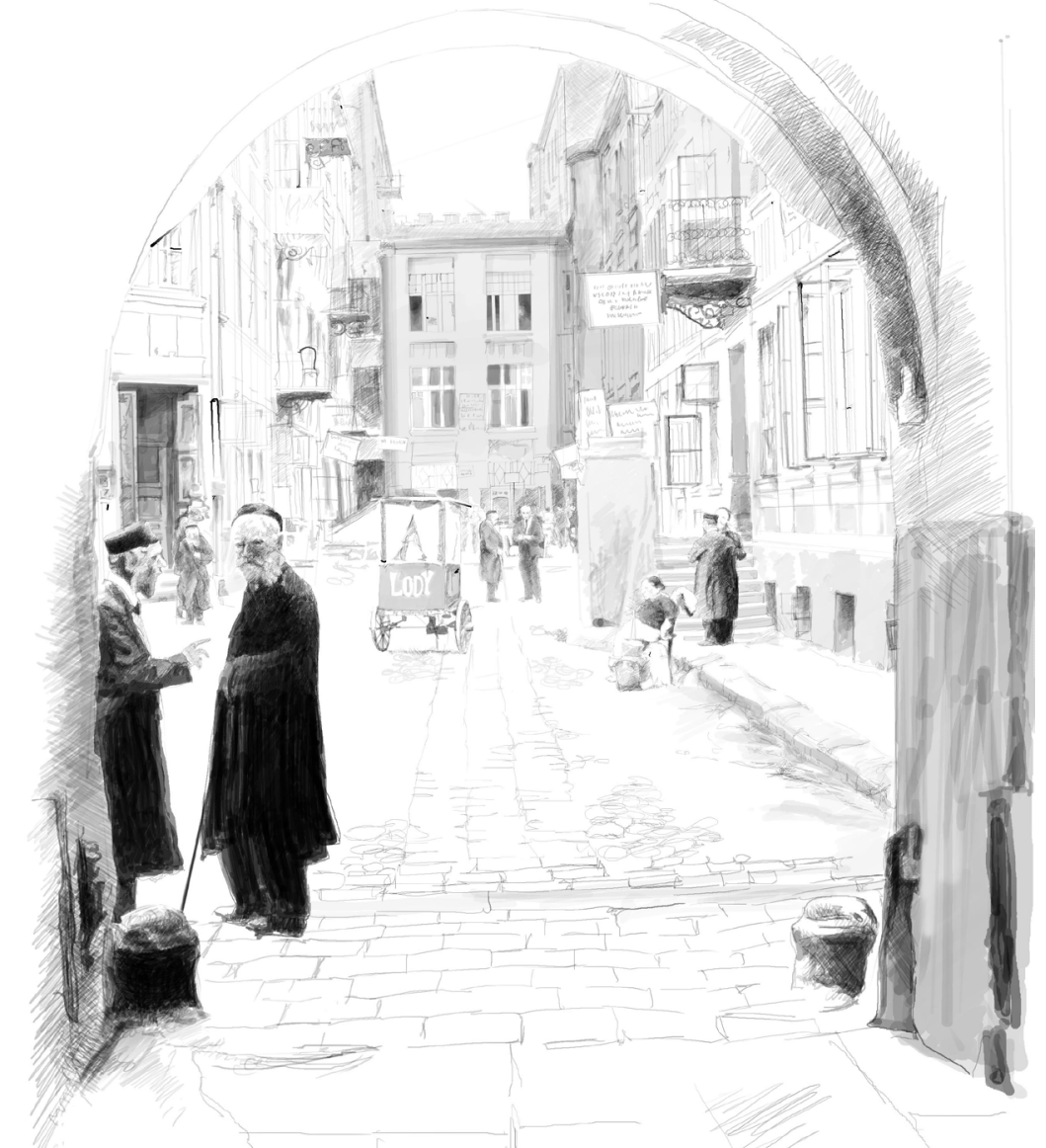

Figure 5. Courtyard. Sketch based on a photograph by Włodzimierz Pfeiffer courtesy of the State Archives in Lódź 


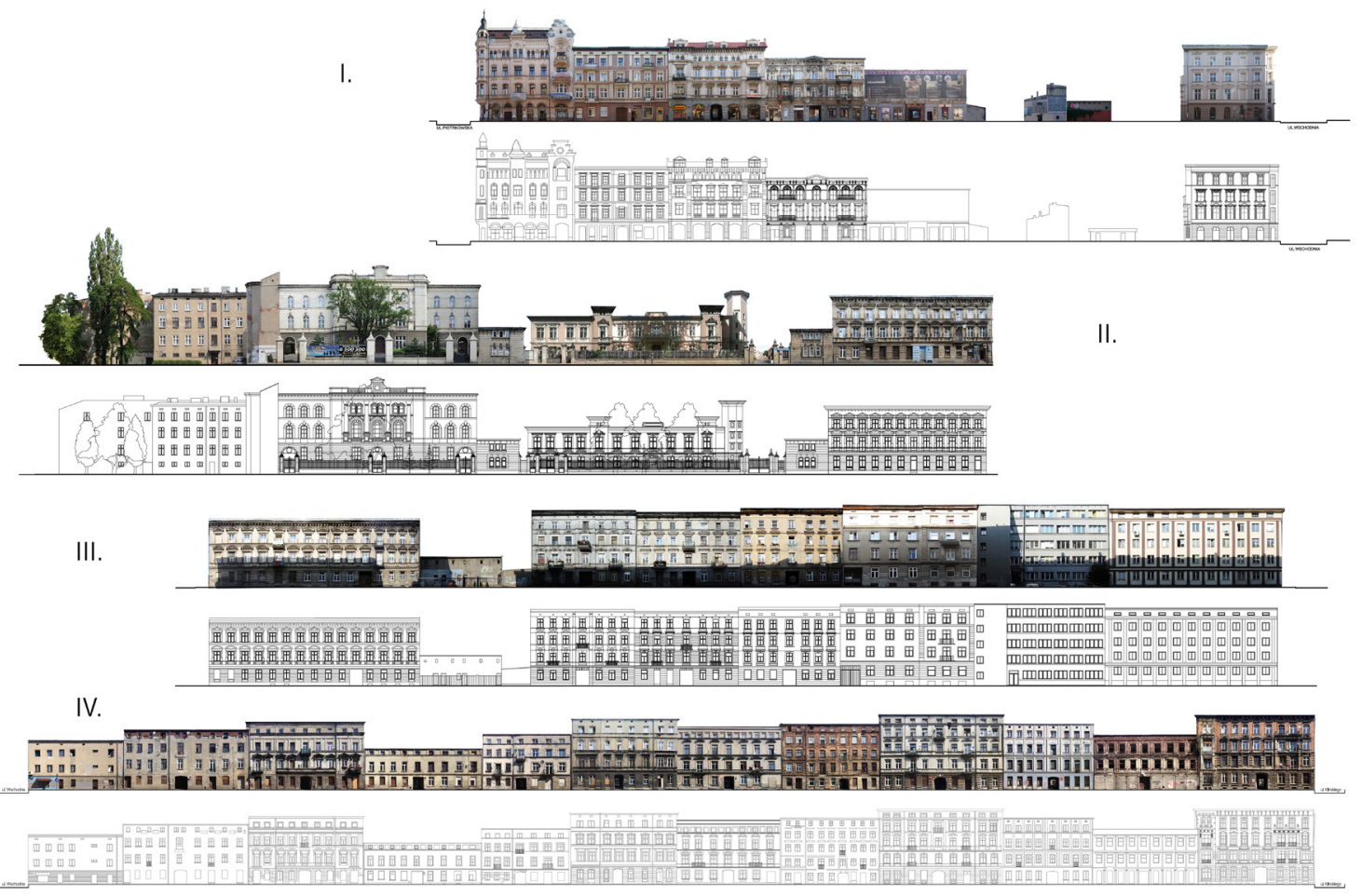

Figure 4. Facades of streets in the part of Nowe Miasto with a large share of the Jewish population. Inventory by students from the Institute of Architecture and Town Planning, Lodz University of Technology, as part of the course: Urban Inventory, BArch., tutor M. Hanzl, works of students: W. Depczynska, A. Jaruga, A. Kowalczyk, A. Pawlowska, N. Rucinska, M. Wroblewska, K. Zasada, A. Żuchlinska, A. Zbrojewska, J. Sobczak. 


\section{Acknowledgements}

The current study is a part of the research project financed by The National Science Centre of Poland UMO-2011/03/D/HS3/01630, entitled: "Morphological analysis of urban structures the cultural approach. Case studies of Jewish communities in the chosen settlements of Lodz and Masovian voivodeships". Part of the methodological research was performed in SENSEable City Laboratory, Massachusetts Institute of Technology within the framework of a Fulbright Senior Research Award

\section{References}

Arbour \& Associés (2001) Faubourg Québec, paramètres de développement urbain (Société de développement de Montréal, Montréal).

Eco, U. (1997) 'Function and Sign: The Semiotics of Architecture', in Leich, N. (ed.) Rethinking Architecture: A reader in cultural theory (Routledge Taylor \& Francis Group, London) 182-202.

Hall, E. T. (1966) Hidden Dimension. Garden City, NY: Doubleday.

Hall, E. T. (2009) 'Proxemics', in Setha M. Low \& Denise L. Lawrence-Zuniga (eds.) The Anthropology of Space and Place, Locating Culture. Oxford: Blackwell Publishing. pp. 51-73.

Hanzl, M. (2017) Morphological analysis of urban structures - the cultural approach. Case studies of Jewish communities in Lodz and Mazovian voivoideships. Wydawnictwo Politechniki Łódzkiej.

Hillier, B. and Hanson, J. (2003) The Social Logic of Space (Cambridge University Press, Cambridge).

Hillier, B. (2012) 'The Genetic Code for Cities: Is It Simpler than We Think?', in Juval Portugali et al. (eds.) Complexity Theories of Cities Have Come of Age: An Overview with Implications to Urban Planning and Design (Springer, Berlin Heidelberg) 129152.

Hubka, T. C. (2005) 'The Shtetl in Context: The Spatial and Social Organization of Jewish Communities from the Small Towns of 18th Century Poland', in Early Modern Workshop: Jewish History Resources (University of Maryland, Maryland, http:// wesscholar.wesleyan.edu/cgi/viewcontent. cgi? article $=1021 \&$ context $=$ emw) accessed 23 June 2016.

GUSRP, 1925. Skorowidz miejscowości Rzeczypospolitej Polskiej opracowany na podstawie wyników Pierwszego Powszechnego Spisu Ludności z dn. 30 września 1921 r. i innych źródeł urzędowych (Główny Urząd Statystyczny Rzeczypospolitej Polskiej, Warszawa, http:// mbc.cyfrowemazowsze.pl).

Lefebvre, H. (2003) The Urban Revolution (University of Minnesota Press, Minneapolis, London).

Portugali, J. (2000) Self-Organization and the City, (Springer-Verlag, Berlin Heidelberg).

Portugali, J. (2006) 'Complexity theory as a link between space and place', Environment and Planning A 38(4) 647-664.

Rapoport, A. (1990) The Meaning of the Built Environment. A Nonverbal Communication Approach (The University of Arizona Press, Tuscon).

Rykała, A. (2012) 'Żydowskie domy modlitwy w Łodzi - uwarunkowania rozwoju przestrzennego, rozmieszczenie, współczesne relikty i ich wykorzystanie' Acta Universitatis Lodziensis, Folia Geographica Socio-Oeconomica. 12221244. 